\title{
Price Discovery of Currency Futures at NSE
}

\author{
Jerlin Jose $^{1}$, Gangu Naidu Mandala ${ }^{1}$, Kavitha Desai ${ }^{1}$, Nilofer Hussaini ${ }^{1}$, Shaik Shamshuddin ${ }^{2}$ \\ ${ }^{1}$ Department of Professional Studies, Christ University, India \\ ${ }^{2}$ Department of Management Studies, Gandhi Institute of Technology and Management, India
}

Received March 14, 2021; Revised June 7, 2021; Accepted June 20, 2021

\section{Cite This Paper in the following Citation Styles}

(a): [1] Jerlin Jose, Gangu Naidu Mandala, Kavitha Desai, Nilofer Hussaini, Shaik Shamshuddin, "Price Discovery of Currency Futures at NSE," Universal Journal of Accounting and Finance, Vol. 10, No. 1, pp. 276 - 285, 2022. DOI: 10.13189/ujaf.2022.100128.

(b): Jerlin Jose, Gangu Naidu Mandala, Kavitha Desai, Nilofer Hussaini, Shaik Shamshuddin (2022). Price Discovery of Currency Futures at NSE. Universal Journal of Accounting and Finance, 10(1), 276 - 285. DOI: 10.13189/ujaf.2022.100128.

Copyright $\bigcirc 2022$ by authors, all rights reserved. Authors agree that this article remains permanently open access under the terms of the Creative Commons Attribution License 4.0 International License

\begin{abstract}
The current study aimed to examine the causal relationship between the NSE currency future rates and currency spot rates in order to identify the price discovery mechanism at NSE market and its integration with foreign exchange market (spot market). To study the causal relationship between the said markets, we have considered daily closing rates for NSE currency futures and currency spot rates for selected pairs of currencies, i.e. USD/INR, GBP/INR, JPY/INR and EURO/INR. The data was obtained from www.nseindia.com and www.investing.com for the period from Jan-2010 to Sep-2017, which makes approximately 1750 observations for each currency pair in each market. It is found that the spot rate for JPY/INR leads the future rate. It is also identified that the spot rate for USD/INR does not cause the changes in futures. It indicates that the market integration between spot and futures at NSE for currency pair USD/INR is strong compared to other selected currency pairs. From the variance decomposition test we found that there is almost no impact of variance in USD/INR spot rate on future rate variance forecast errors. It implies that the causal relationship between for USD/INR spot and future rates is strong and mature compared to the measured causal relationships for the remaining currency pairs. This study concludes that the price discovery process for currency pair USD/INR is better at NSE currency futures among the selected currency pairs.
\end{abstract}

Keywords Currency Futures, Foreign Exchange Market, NSE, Spot Market

\section{Introduction}

Foreign exchange market is the world's largest market in terms of trade value is estimated at $\$ 5.09$ trillion (Bank for International Settlements) in the year 2016. The importance of foreign exchange management is gaining significance because the market is growing larger day by day. Foreign exchange trading in India introduced in the year when Reserve Bank of India allowed banks to undertake intraday trading in foreign exchange segment. A foreign exchange rate is highly volatile and responds to all global factors directly and indirectly. International trading community has greater interest in foreign exchange rates since their business significantly affected by the exchange rates. A currency derivative comes in handy for the traders and can be used as a tool for mitigating future exchange rate risk.

Currency derivatives in India launched at national stock exchange with the introduction of currency futures against USD in the year 2008 and subsequently allowed to trade against other strong currencies like EURO, POUND and YEN. Though the magnitude of exchange traded currency derivatives against over the counter trade is very small, the currency derivatives are exceptionally doing well at NSE F\&O segment. Total traded turnover of Currency derivatives at NSE for the year 2016 stood at Rs 48, 57,075 Cr. with the average daily turnover of Rs $19,394.83 \mathrm{Cr}$.

World federation of exchanges reports that the currency derivative trade volume has increased significantly during the period of 2015-2016 in both futures and options. While the market has increased in the North American region by $14 \%$ during this period, the Asia-Pacific region has 
witnessed tremendous growth rate of $23 \%$ which is driven by BSE and NSE with growth rate of $23 \%$ and $22 \%$ respectively.

Table 1. Changes in Currency Options and Futures 2015-2016

\begin{tabular}{|c|c|c|c|c|c|}
\hline & $\mathbf{2 0 1 5}$ & $\mathbf{2 0 1 6}$ & $\begin{array}{c}\% \\
\text { change }\end{array}$ & $\begin{array}{c}\% \text { of total } \\
\text { (asset } \\
\text { class) }\end{array}$ & $\begin{array}{c}\text { \% of } \\
\text { total } \\
\text { overall) }\end{array}$ \\
\hline $\begin{array}{c}\text { Currency } \\
\text { Options }\end{array}$ & & 650 & $39.3 \%$ & $18 \%$ & $18 \%$ \\
\hline $\begin{array}{c}\text { Currency } \\
\text { Futures }\end{array}$ & 2115 & 2199 & $4.0 \%$ & $82 \%$ & $82 \%$ \\
\hline $\begin{array}{c}\text { Total } \\
\text { Currency }\end{array}$ & 2581 & 2850 & $10.4 \%$ & & $18 \%$ \\
\hline
\end{tabular}

The report also validates that the currency derivatives on NSE, i.e. both futures and options available on USD/INR are most traded currency derivatives in the world for the year 2016-17 after USD/RUB futures that are traded on the Moscow Exchange.

With the constant changes of international businesses, traders are in need of efficient foreign exchange management. Currency derivatives are complex and yet powerful risk management tools and are applied heavily in foreign exchange management. It provides several benefits to the market participants such as hedging, arbitration opportunities, and investment leverage.

Source: World Federation of Exchanges (WFE)

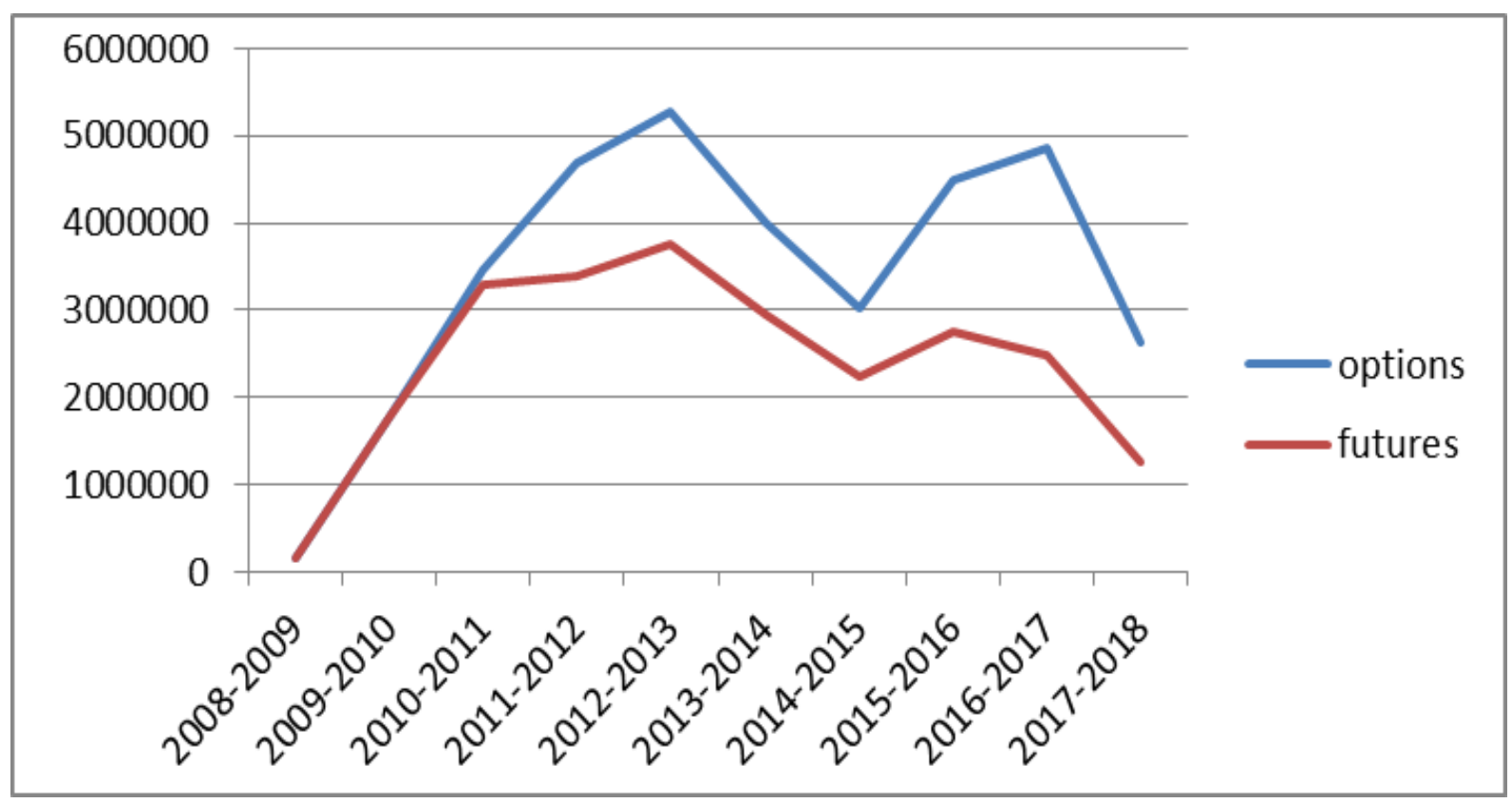

Source: www.nseindia.com

Figure 1. Growth of Currency Derivatives at NSE since Inception in Rs. Cr

Table 2. Top 10 currency contracts traded in 2016

\begin{tabular}{|c|c|c|c|c|c|c|c|c|}
\hline & \multirow[b]{2}{*}{ Contract Name } & \multirow[b]{2}{*}{ Exchange } & \multicolumn{2}{|c|}{ Volume } & \multicolumn{2}{|c|}{ Notional Value } & \multicolumn{2}{|c|}{ Open Interest } \\
\hline & & & 2016 & AGR & 2016 & AGR & 2016 & AGR \\
\hline 1 & USD/RUB futures & Moscow Exchange & 865068634 & $-4 \%$ & 980880 & $26 \%$ & 2626442 & $-10 \%$ \\
\hline 2 & USDINR Options & NSE India ltd & 351632420 & $63 \%$ & 351609 & $66 \%$ & NA & NA \\
\hline 3 & USDINR Futures & NSE India Ltd. & 351162981 & $-2 \%$ & 349620 & $0 \%$ & NA & NA \\
\hline 4 & USDINR Futures & BSE Ltd. & 319413292 & $24 \%$ & NA & NA & NA & NA \\
\hline 5 & USDINR Options & BSE Ltd. & 207386529 & $22 \%$ & NA & NA & NA & NA \\
\hline 6 & $\begin{array}{c}\text { Mini U.S. Dollar } \\
\text { Futures }\end{array}$ & BM\& FBOVESPA & 92119754 & NA & 981794 & NA & 508417 & NA \\
\hline 7 & U.S. Dollar Futures & BM\& FBOVESPA & 71281293 & $-8 \%$ & 3832059 & $16 \%$ & 13388898 & $1059 \%$ \\
\hline 8 & EURO FX & CME Group & 49455909 & $-24 \%$ & 6848045 & $-32 \%$ & 408748 & $2 \%$ \\
\hline 9 & USD Futures & Korea Exchange & 56869526 & $8 \%$ & 54775617 & $10692 \%$ & 777433 & $27 \%$ \\
\hline 10 & $\begin{array}{l}\text { JAPANESE YEN } \\
\text { futures }\end{array}$ & CME Group & 36588788 & $1 \%$ & 4201948 & $12 \%$ & 212942 & $4 \%$ \\
\hline
\end{tabular}

Source: WORLD FEDERATION OF EXCHANGES (WFE) 


\section{Literature Review}

Since the currency futures market facilitates an advantage for the investor through marginal investment, many researchers argue that the informational investors would opt for the futures market over spot market. Thus, currency futures market would attract all the informed traders and rates are adjusted accordingly. This would further lead the spot market exchange rates. Contrary to this argument, some researchers advise that the current currency needs to be settled in cash, hence the currency demand and supply would be absorbed into the spot rates. The study documents the finding of a survey of brokers' perception, introduced commodity derivatives market in India [1]. The survey results show the brokers' assessment about trading/marketing activities and their perception of the benefits and concerns about commodity derivatives. It also throws some light on the perception of brokers about the efficiency of Indian commodity derivatives in performing the functions of price discovery, hedging effectiveness and volatility dynamics.

In another article, it is outlined that the UK contribution to BIS and focus largely changes in FX markets. Many studies have examined the relationship between currency spot and futures markets [2]. Chan's study provides evidence that this price discovery process cannot be based on adverse selection between dealers and their customers, as postulated in standard models, because the spreads dealers quote to their customers are not positively related to a trade's likely information content.

Sehgal et al., [3] dynamic interdependence via growth spillovers between financial cycles represented by real bank credit growth and business cycle as real GDP growth and also examined the price discovery and volatility spillovers in spot and futures.

The current study aims to examine the causal relationship between the NSE currency future rates and currency spot rates in order to identify the price discovery mechanism at NSE market and its integration with foreign exchange market (spot market). To study the causal relationship between the said markets, we have considered daily closing rates for NSE currency futures and currency spot rates for selected pairs of currencies, i.e. USD/INR, GBP/INR, JPY/INR and EURO/INR. The data obtained from www.nseindia.com and www.investing.com for the period from Jan-2010 to Sep-2017, which makes approximately 1750 observations for each currency pair in each market [4].

The study of Sakthive et al. [5] observed that the spot market adjusts to new information faster than futures market suggesting that spot price leads the futures price and contributes largely to price discovery the results of the study show that there is unidirectional volatility transmission from currency spot to futures prices of JPY/INR, GBP/INR and EUR/INR and bidirectional spillover between currency spot and futures prices of USD/INR. Based on the findings, relevant policy recommendations are made.
Price discovery could be referred to as the use of the futures price to discover the prices existing in the spot market, which further depends upon the strength of the relationship between the prices of the futures contracts and their underlying. The following study is aimed at investigating the relationship between the spot rates of INR-USD, INR-GBP, INR-Euro and INR-Yen exchange rates and the futures contracts for the same pairs traded in Indian financial markets.

The study of Gonzalo [6] consisted of the competitiveness and their connection with real exchange rate misalignments. It will then summarize a range of methodologies available for assessing real exchange misalignments, outlining potential obstacles and providing some suggestions for how these can be overcome. Study has not tested the convergence empirically, but seeing the pattern of trading and the study on market efficiency in India supports the dependency of two on each other i.e., there is a long-term stable relationship between foreign currency spot and futures market.

Many studies have examined the relationship between currency spot and futures markets. A majority of studies suggested that the futures lead the spot prices [7], [8] while some have advised otherwise. In the foreign exchange market, the currency futures market share is much smaller than the currency spot market, and it is argued that a significance of currency futures in determining spot rate is very less [9]. However, 2007 BIS Triennial survey, suggested that the currency futures market plays a significant role in price discovery process compared to the spot market. [10] examined the lead-lag relationship between NSE currency futures rates and spot currency rates using daily closing rates under a VECM model and concluded that the future rates lead the spot rates. It is also found that the futures lead spot in all pairs of currencies available at NSE i.e., USD/INR, GBP/INR, JPY/INR and EURO/INR.

The current study aimed to examine the causal relationship between the NSE currency future rates and currency spot rates in order to identify the price discovery mechanism at NSE market and its integration with foreign exchange market (spot market). To study the causal relationship between the said markets, we have considered daily closing rates for NSE currency futures and currency spot rates for selected pairs of currencies, i.e. USD/INR, GBP/INR, JPY/INR and EURO/INR. The data obtained from www.nseindia.com and www.investing.com for the period from Jan-2010 to Sep-2017, which makes it approximately 1750 observations for each currency pair in each market.

The Granger Causality Test is an appropriate method of identifying the lead-lag relationship between the time series data. It is necessary to have the variables stationarity in order to proceed further to test the Granger Causality. Hence, we applied the Augmented Dicky Fuller test in order to test the stationarity of the data. The table 3 summarizes the results from the ADF. 
Table 3. ADF test of NONSTATIONARITY

\begin{tabular}{|c|c|c|c|c|}
\hline \multicolumn{5}{|c|}{ Null Hypothesis: Unit root (individual unit root process) } \\
\hline \multicolumn{5}{|c|}{$\begin{array}{l}\text { Series: DEURFUT, DEURSPOT, DGBPFUT, DGBPSPOT, DJPYFUT, } \\
\text { DJPYSPOT, DUSDFUT, DUSDSPOT, EURFUT, EUROSPOT, } \\
\text { GBPFUT, GBPSPOT, JPYFUT, JPYSPOT, USDFUT, USDSPOT }\end{array}$} \\
\hline \multicolumn{5}{|c|}{ Sample: $1 / 01 / 2010$ 10/18/2017 } \\
\hline \multicolumn{5}{|c|}{ Exogenous variables: Individual effects } \\
\hline \multicolumn{5}{|c|}{ Automatic selection of maximum lags } \\
\hline \multicolumn{5}{|c|}{ Automatic lag length selection based on AIC: 1 to 9} \\
\hline \multicolumn{5}{|c|}{ Total number of observations: 24170} \\
\hline \multicolumn{5}{|c|}{ Cross-sections included: 16} \\
\hline Method & & & Statistic & Prob.** \\
\hline \multicolumn{3}{|l|}{ ADF - Fisher Chi-square } & 1219.32 & 0.0000 \\
\hline \multicolumn{3}{|l|}{ ADF - Choi Z-stat } & -23.3688 & 0.0000 \\
\hline \multicolumn{5}{|c|}{ ** Probabilities for Fisher tests are computed using an asymptotic Chi } \\
\hline \multicolumn{5}{|c|}{-square distribution. All other tests assume asymptotic normality. } \\
\hline \multicolumn{5}{|c|}{ Intermediate ADF test results UNTITLED } \\
\hline Series & Prob. & Lag & Max Lag & Obs \\
\hline DEURFUT & 0.0000 & 3 & 9 & 1046 \\
\hline DEURSPOT & 0.0000 & 4 & 25 & 2015 \\
\hline DGBPFUT & 0.0000 & 1 & 9 & 1302 \\
\hline DGBPSPOT & 0.0000 & 1 & 25 & 2031 \\
\hline DJPYFUT & 0.0000 & 3 & 9 & 1046 \\
\hline DJPYSPOT & 0.0000 & 1 & 25 & 2018 \\
\hline DUSDFUT & 0.0000 & 8 & 9 & 596 \\
\hline DUSDSPOT & 0.0000 & 1 & 25 & 2031 \\
\hline EURFUT & 0.4946 & 4 & 9 & 1046 \\
\hline EUROSPOT & 0.5433 & 5 & 25 & 2015 \\
\hline GBPFUT & 0.6011 & 2 & 9 & 1302 \\
\hline GBPSPOT & 0.5591 & 2 & 25 & 2031 \\
\hline JPYFUT & 0.5470 & 4 & 9 & 1046 \\
\hline JPYSPOT & 0.1810 & 2 & 25 & 2018 \\
\hline USDFUT & 0.8896 & 9 & 9 & 596 \\
\hline USDSPOT & 0.5591 & 2 & 25 & 2031 \\
\hline
\end{tabular}

The above test result exhibits that all the future rates and spot rates at level are non-stationary since the ' $p$ ' values is greater than .05 which fails to reject the null hypothesis of unit root (Non-stationary). The variables at first difference found to be stationary since the p value is less than .05 and rejecting the null hypothesis of non-stationary. Since, the variables at level i.e. without any order of difference found non stationary; it cannot be applied in Granger causality test. Therefore, the variables at first difference can be used in testing Granger Causality Test.

\section{Granger Causality Test}

The Granger Causality Test is applied for each pair of currency using first differenced data from both spot and futures markets. The following table 4 exhibits the result from granger causality test for EURO/INR spot and future rates and it implies that there is bi-directional causality between EURO/INR spot and future markets since the $p$ values for both hypothesis are less than .05 significance level and suggesting the rejection of null hypotheses.

Table 4. Granger causality test for EURO/INR spot and future rate

\begin{tabular}{|l|c|c|c|}
\hline \multicolumn{4}{|l|}{ Pair wise Granger Causality Tests } \\
\hline Sample: $1 / 01 / 2010$ 10/18/2017 & & \\
\hline Lags: 2 & Obs & F-Statistic & Prob. \\
\hline Null Hypothesis: & 1293 & 197.312 & 0.00 \\
\hline $\begin{array}{l}\text { DEURSPOT does not Granger Cause } \\
\text { DEURFUT }\end{array}$ & 10.8452 & 0.00 \\
\hline $\begin{array}{l}\text { DEURFUT does not Granger Cause } \\
\text { DEURSPOT }\end{array}$ & &
\end{tabular}

The following table 5 exhibits the result from Granger Causality Test for GBP/INR spot and future rates. The system automatically selected the lag length of 2 using 
Akaike Information Criterion (AIC) for the model estimation. The result implies that there is bi-directional causality between GBP/INR spot and future markets since the $\mathrm{p}$ values for both hypotheses is less than 5\% significance level and suggesting the rejection of null hypotheses.

Table 5. Granger causality test for GBP/INR spot and future rate

\begin{tabular}{|l|l|l|l|}
\hline \multicolumn{4}{|l|}{ Pair wise Granger Causality Tests } \\
\hline Sample: $1 / 01 / 2010$ 10/18/2017 & & \\
\hline Lags: 2 & Obs & F-Statistic & Prob. \\
\hline Null Hypothesis: & 1302 & 103.319 & 0.00 \\
\hline $\begin{array}{l}\text { DGBPSPOT does not Granger } \\
\text { Cause DGBPFUT }\end{array}$ & 21.8932 & 0.01 \\
\hline $\begin{array}{l}\text { DGBPFUT does not Granger Cause } \\
\text { DGBPSPOT }\end{array}$
\end{tabular}

The following table 6. exhibits the result from Granger Causality Test for JPY/INR spot and future rates and it implies that there is uni-directional causality from JPY/INR spot rates to future market rates since the $p$ values for null hypothesis "DJPYSPOT does not Granger Cause DJPYFUT" is less than .05 significance level and suggesting the rejection of the null hypotheses. It signifies that JPY/INR future rate does not cause JPY/INR spot rate.

Table 6. Granger causality test for JPY/INR spot and future rate

\begin{tabular}{|l|c|c|c|}
\hline \multicolumn{3}{|l|}{ Pair wise Granger Causality Tests } \\
\hline Sample: $1 / 01 / 201010 / 18 / 2017$ & & \\
\hline Lags: 2 & Obs & F-Statistic & Prob. \\
\hline Null Hypothesis: & 1293 & 147.461 & 0.0011 \\
\hline $\begin{array}{l}\text { DJPYSPOT does not Granger } \\
\text { Cause DJPYFUT }\end{array}$ & 0.18529 & 0.8309 \\
\hline $\begin{array}{l}\text { DJPYFUT does not Granger Cause } \\
\text { DJPYSPOT }\end{array}$ & &
\end{tabular}

The following table 7 exhibits the result from granger causality test for USD/INR spot and future rates and it implies that there is uni-directional causality from USD/INR futures rate to spot market rates since the $p$ values for null hypothesis "DUSDFUT does not Granger Cause DUSDSPOT" is less than .05 significance level and suggesting the rejection of the null hypotheses. It signifies that USD/INR spot rate does not cause USD/INR future rate.

Table 7. Granger causality test for USD/INR spot and future rate

\begin{tabular}{|l|c|c|c|}
\hline \multicolumn{3}{|l|}{ Pair wise Granger Causality Tests } \\
\hline Sample: $1 / 01 / 201010 / 18 / 2017$ & & \\
\hline Lags: 2 & Obs & F-Statistic & Prob. \\
\hline Null Hypothesis: & 1319 & 0.43450 & 0.6477 \\
\hline $\begin{array}{l}\text { DUSDSPOT does not Granger } \\
\text { Cause DUSDFUT }\end{array}$ & 3.58609 & 0.0280 \\
\hline $\begin{array}{l}\text { DUSDFUT does not Granger Cause } \\
\text { DUSDSPOT }\end{array}$ & &
\end{tabular}

Variance Decomposition: Although the causal relationship between spot and futures identified in the previous analysis, it does not disclose relative strength of the variables in the VAR system to the exogenous shocks. Variance decomposition is a method of identifying forecast error variance of each variable from a vector autoregressive (VAR) system. The results from this method are very sensitive to the ordering of variables which generally follows Cholesky's ordering. The Cholesky decomposition algorithm was first proposed by Andre-Louis Cholesky (October 15, 1875 - August 31, 1918) at the end of the First World War. He was a French military officer and mathematician. The idea of this algorithm was published in 1924 by his fellow officer and, later, was used by Banachiewicz in 1938. In the Russian mathematical literature, the Cholesky decomposition is also known as the square-root method. The variance decomposition technique applied for each VAR model estimated separately for each currency pair data sampled from spot and future market. The result would be used to identify the response in endogenous variable caused by shock in each exogenous variable in the estimated VAR. Table 8 represents the output from variance decomposition analysis from estimated VAR of USD/INR spot rate and future rates. The result depicts that only $0.06 \%$ variance in USD/INR futures rate caused by shock in USD/INR spot rate which is insignificant. It also indicates that the $27 \%$ of variation in USD/INR spot rate caused by shock in USD/INR future rate signifying the impact of future rate on spot rate. 
Table 8. Variance Decomposition of USD/INR spot rate and future rates

\begin{tabular}{|c|c|c|c|}
\hline \multicolumn{4}{|c|}{ Variance Decomposition of DUSDFUT: } \\
\hline Period & S.E. & DUSDFUT & DUSDSPOT \\
\hline 1 & 0.280320 & 100.0000 & 0.000000 \\
\hline 2 & 0.280423 & 99.94293 & 0.057066 \\
\hline 3 & 0.281327 & 99.93462 & 0.065380 \\
\hline 4 & 0.281327 & 99.93409 & 0.065914 \\
\hline 5 & 0.281334 & 99.93401 & 0.065985 \\
\hline 6 & 0.281334 & 99.93401 & 0.065989 \\
\hline 7 & 0.281334 & 99.93401 & 0.065990 \\
\hline 8 & 0.281334 & 99.93401 & 0.065990 \\
\hline 9 & 0.281334 & 99.93401 & 0.065990 \\
\hline 10 & 0.281334 & 99.93401 & 0.065990 \\
\hline \multicolumn{4}{|c|}{ Variance Decomposition of DUSDSPOT: } \\
\hline Period & S.E. & DUSDFUT & DUSDSPOT \\
\hline 1 & 0.619856 & 26.69215 & 73.30785 \\
\hline 2 & 0.620370 & 26.70954 & 73.29046 \\
\hline 3 & 0.622602 & 27.20804 & 72.79196 \\
\hline 4 & 0.622605 & 27.20809 & 72.79191 \\
\hline 5 & 0.622623 & 27.21208 & 72.78792 \\
\hline 6 & 0.622623 & 27.21208 & 72.78792 \\
\hline 7 & 0.622623 & 27.21211 & 72.78789 \\
\hline 8 & 0.622623 & 27.21211 & 72.78789 \\
\hline 9 & 0.622623 & 27.21211 & 72.78789 \\
\hline 10 & 0.622623 & 27.21211 & 72.78789 \\
\hline \multicolumn{4}{|c|}{ Cholesky Ordering: DUSDFUT DUSDSPOT } \\
\hline
\end{tabular}

Variance Decomposition of DUSDFUT

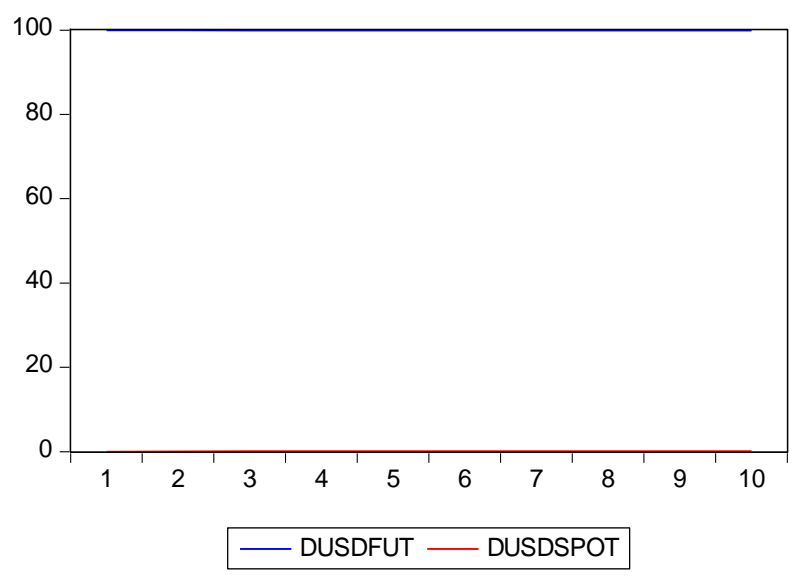

Variance Decomposition of DUSDSPOT

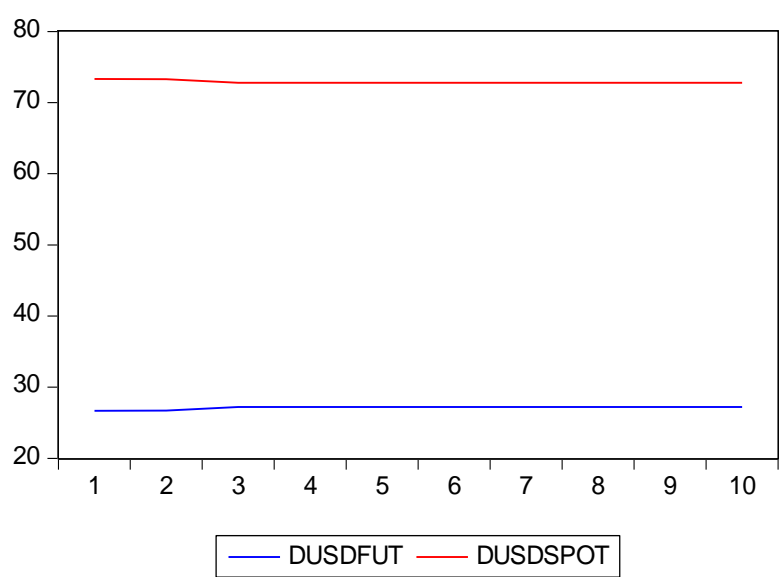

Graph 1. 
Table 9 represents the output from variance decomposition analysis from estimated VAR of JPY/INR spot rate and future rates. The result depicts that only $18 \%$ variance forecast error in JPY/INR futures rate caused by shock in JPY/INR spot rate over the period of 10 days which is relatively insignificant. It also indicates that the $55.8 \%$ of variation in JPY/INR spot rate caused by shock in JPY/INR future rate indicating significant impact of future rate on spot rate.

Table 9. Variance Decomposition of JPY/INR spot rate and future rates

\begin{tabular}{|c|c|c|c|}
\hline \multicolumn{4}{|c|}{ Variance Decomposition of DJPYFUT: } \\
\hline Period & S.E. & DJPYFUT & DJPYSPOT \\
\hline 1 & 0.429883 & 100.0000 & 0.000000 \\
\hline 2 & 0.473246 & 82.51928 & 17.48072 \\
\hline 3 & 0.474305 & 82.17570 & 17.82430 \\
\hline 4 & 0.475882 & 81.82200 & 18.17800 \\
\hline 5 & 0.476191 & 81.71857 & 18.28143 \\
\hline 6 & 0.476210 & 81.71740 & 18.28260 \\
\hline 7 & 0.476214 & 81.71709 & 18.28291 \\
\hline 8 & 0.476216 & 81.71668 & 18.28332 \\
\hline 9 & 0.476216 & 81.71662 & 18.28338 \\
\hline 10 & 0.476216 & 81.71662 & 18.28338 \\
\hline \multicolumn{4}{|c|}{ Variance Decomposition of DJPYSPOT: } \\
\hline Period & S.E. & DJPYFUT & DJPYSPOT \\
\hline 1 & 0.014080 & 55.82651 & 44.17349 \\
\hline 2 & 0.014083 & 55.83978 & 44.16022 \\
\hline 3 & 0.014123 & 55.89901 & 44.10099 \\
\hline 4 & 0.014123 & 55.89890 & 44.10110 \\
\hline 5 & 0.014123 & 55.89936 & 44.10064 \\
\hline 6 & 0.014123 & 55.89930 & 44.10070 \\
\hline 7 & 0.014123 & 55.89929 & 44.10071 \\
\hline 8 & 0.014123 & 55.89929 & 44.10071 \\
\hline 9 & 0.014123 & 55.89929 & 44.10071 \\
\hline 10 & 0.014123 & 55.89929 & 44.10071 \\
\hline \multicolumn{4}{|c|}{ Cholesky Ordering: DJPYFUT DJPYSPOT } \\
\hline
\end{tabular}

Variance Decomposition of DJPYFUT

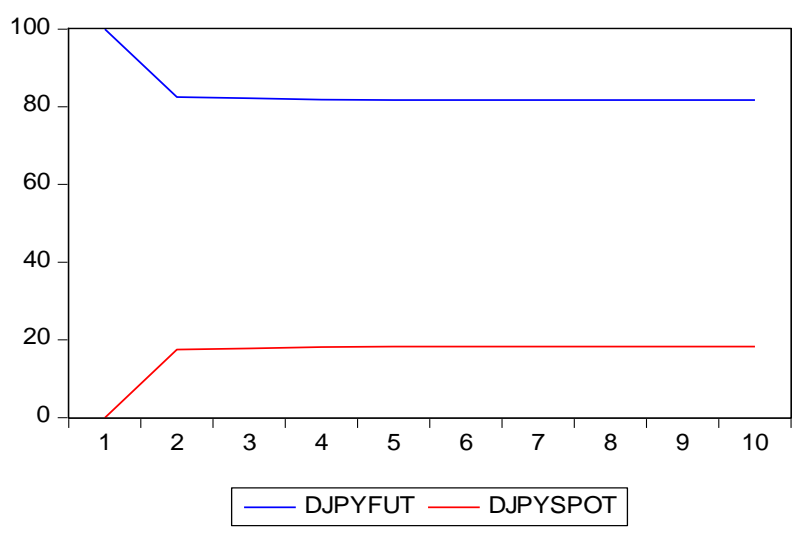

Variance Decomposition of DJPYSPOT

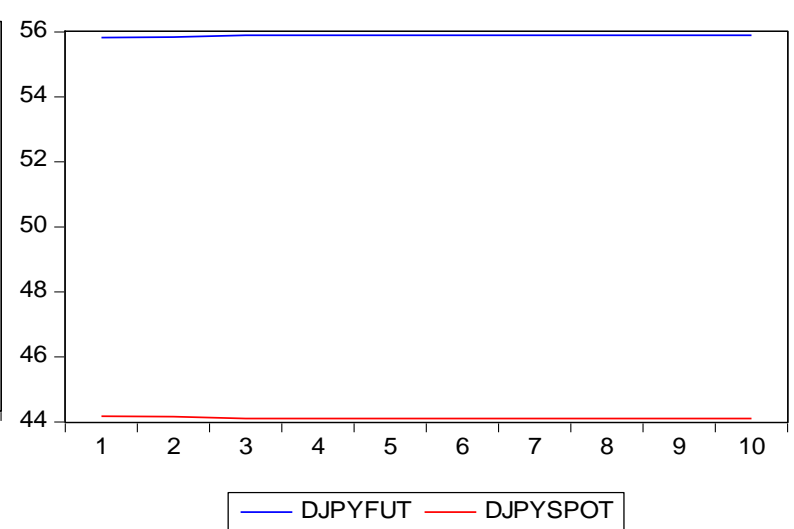

Graph 2 
Table 10 represents the output from variance decomposition analysis from estimated VAR of GBP/INR spot rate and future rates. The result depicts that only $12 \%$ variance forecast error in GBP/INR futures rate caused by shock in GBP/INR spot rate which is found to be insignificant. It also indicates that the $61 \%$ of variation in GBP/INR spot rate caused by shock in GBP/INR future rate in a period of 10 days indicating significant impact of future rate on spot rate.

Table 10. Variance Decomposition of GBP/INR spot rate and future rates

\begin{tabular}{|c|c|c|c|}
\hline \multicolumn{4}{|c|}{ Variance Decomposition of DGBPFUT: } \\
\hline Period & S.E. & DGBPFUT & DGBPSPOT \\
\hline 1 & 0.529465 & 100.0000 & 0.000000 \\
\hline 2 & 0.567846 & 88.37070 & 11.62930 \\
\hline 3 & 0.569556 & 87.90296 & 12.09704 \\
\hline 4 & 0.571089 & 87.69876 & 12.30124 \\
\hline 5 & 0.571450 & 87.58956 & 12.41044 \\
\hline 6 & 0.571515 & 87.57805 & 12.42195 \\
\hline 7 & 0.571519 & 87.57813 & 12.42187 \\
\hline 8 & 0.571522 & 87.57737 & 12.42263 \\
\hline 9 & 0.571523 & 87.57686 & 12.42314 \\
\hline 10 & 0.571524 & 87.57681 & 12.42319 \\
\hline \multicolumn{4}{|c|}{ Variance Decomposition of DGBPSPOT: } \\
\hline Period & S.E. & DGBPFUT & DGBPSPOT \\
\hline 1 & 0.613384 & 60.99715 & 39.00285 \\
\hline 2 & 0.621477 & 60.38337 & 39.61663 \\
\hline 3 & 0.624650 & 60.74757 & 39.25243 \\
\hline 4 & 0.624651 & 60.74737 & 39.25263 \\
\hline 5 & 0.624765 & 60.72553 & 39.27447 \\
\hline 6 & 0.624814 & 60.71591 & 39.28409 \\
\hline 7 & 0.624817 & 60.71582 & 39.28418 \\
\hline 8 & 0.624819 & 60.71574 & 39.28426 \\
\hline 9 & 0.624819 & 60.71560 & 39.28440 \\
\hline 10 & 0.624819 & 60.71558 & 39.28442 \\
\hline \multicolumn{4}{|c|}{ Cholesky Ordering: DGBPFUT DGBPSPOT } \\
\hline
\end{tabular}

Variance Decomposition of DGBPFUT

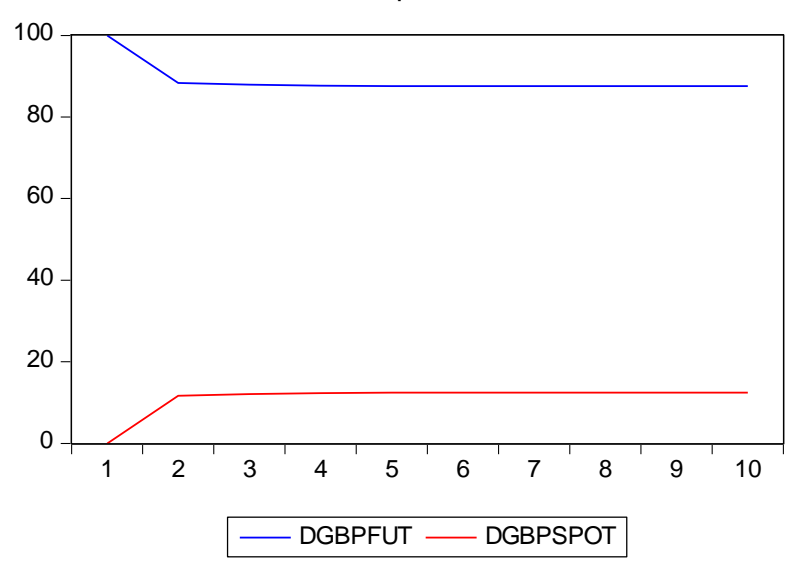

Variance Decomposition of DGBPSPOT

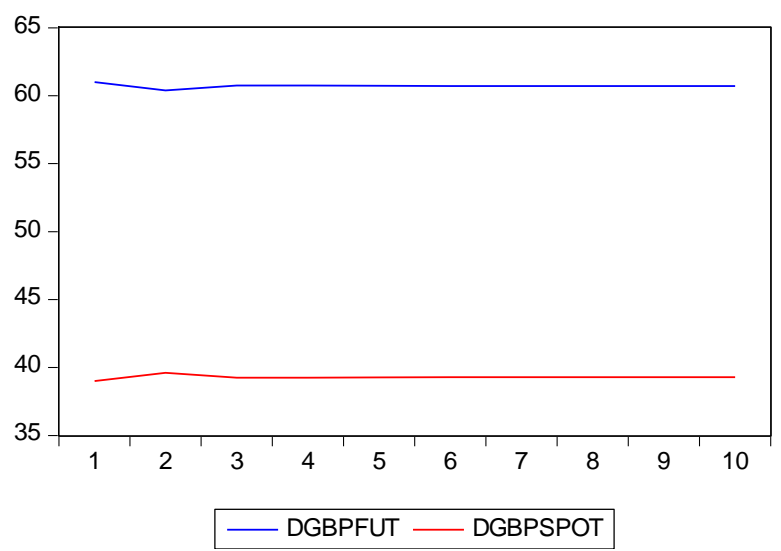

Graph 3. 
Table 11. Variance Decomposition of EUR/INR spot rate and future rates

\begin{tabular}{|c|c|c|c|}
\hline \multicolumn{4}{|c|}{ Variance Decomposition of DEURFUT: } \\
\hline Period & S.E. & DEURFUT & DEURSPOT \\
\hline 1 & 0.399747 & 100.0000 & 0.000000 \\
\hline 2 & 0.450256 & 79.58620 & 20.41380 \\
\hline 3 & 0.453078 & 78.63781 & 21.36219 \\
\hline 4 & 0.454767 & 78.58596 & 21.41404 \\
\hline 5 & 0.455053 & 78.50858 & 21.49142 \\
\hline 6 & 0.455094 & 78.49857 & 21.50143 \\
\hline 7 & 0.455101 & 78.49811 & 21.50189 \\
\hline 8 & 0.455102 & 78.49817 & 21.50183 \\
\hline 9 & 0.455102 & 78.49806 & 21.50194 \\
\hline 10 & 0.455102 & 78.49803 & 21.50197 \\
\hline \multicolumn{4}{|c|}{ Variance Decomposition of DEURSPOT: } \\
\hline Period & S.E. & DEURFUT & DEURSPOT \\
\hline 1 & 0.506717 & 50.37623 & 49.62377 \\
\hline 2 & 0.510506 & 49.85129 & 50.14871 \\
\hline 3 & 0.512942 & 50.32118 & 49.67882 \\
\hline 4 & 0.512980 & 50.32859 & 49.67141 \\
\hline 5 & 0.512994 & 50.32591 & 49.67409 \\
\hline 6 & 0.513007 & 50.32344 & 49.67656 \\
\hline 7 & 0.513008 & 50.32328 & 49.67672 \\
\hline 8 & 0.513009 & 50.32334 & 49.67666 \\
\hline 9 & 0.513009 & 50.32333 & 49.67667 \\
\hline 10 & 0.513009 & 50.32333 & 49.67667 \\
\hline \multicolumn{4}{|c|}{ Cholesky Ordering: DEURFUT DEURSPOT } \\
\hline
\end{tabular}

Variance Decomposition of DEURFUT

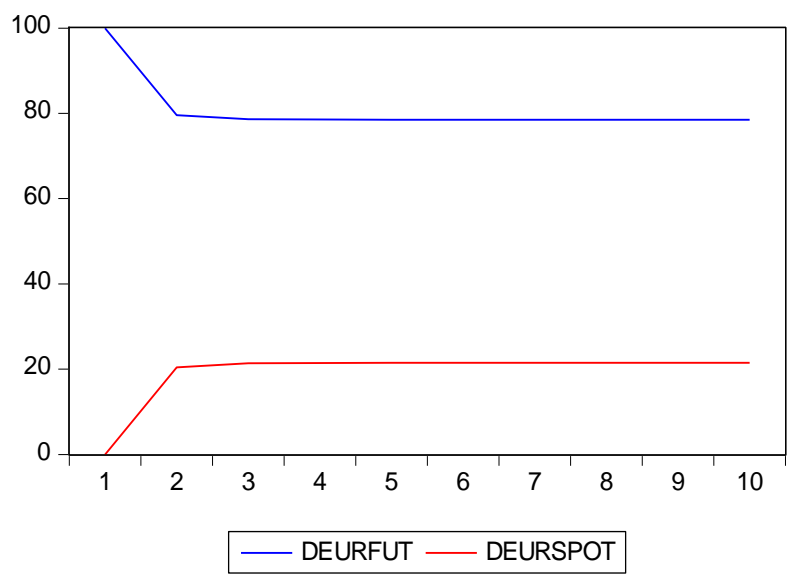

Variance Decomposition of DEURSPOT

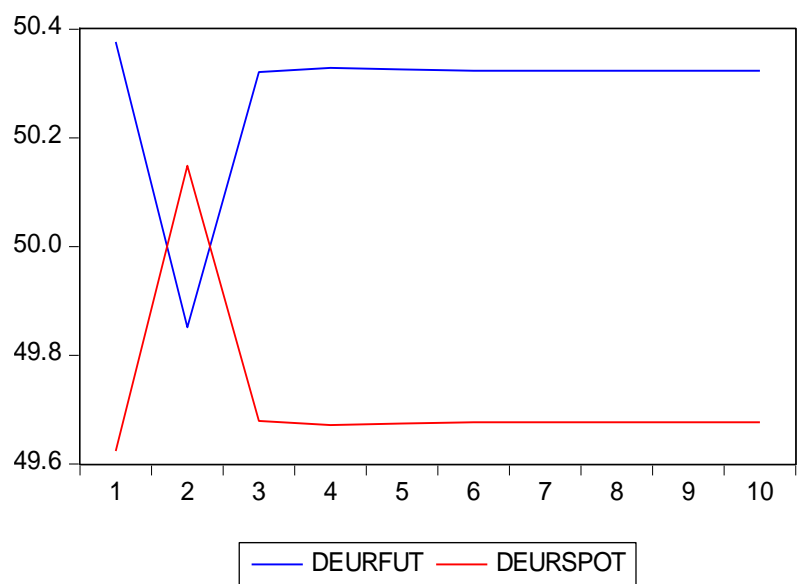

Graph 4.

Table 11 represents the output from variance decomposition analysis from estimated VAR of EUR/INR spot rate and future rates. The result depicts that only 21 per cent variance forecast error in EUR/INR futures rate caused by shock in EUR/INR spot rate over a period of 10 trading days which is insignificant. It also indicates that the 50 per cent of variance forecast error in EUR/INR spot rate caused by shock in EUR/INR future rate in a period of 10 days indicating significant impact of future rate on spot rate.

\section{Conclusions}

The current study aimed at examining the causal relationship between the NSE currency future rates and currency spot rates in order to identify the price discovery mechanism at NSE market. To study the causal relationship between the said markets, we have considered daily closing rates for NSE currency futures and currency spot rates for selected pairs of currencies i.e. USD/INR, GBP/INR, JPY/INR and EURO/INR. Granger Causality 
Test is used for identifying the lead lag relationship between the currency spot and future markets. From this study, we identified that the currency future rates lead spot rates for USD/INR, GBR/INR and EURO/INR currency pairs. It is found that the spot rate for JPY/INR leads the future rate. It is also identified that the spot rate for USD/INR does not cause the changes in futures. It indicates that the market integration between spot and futures at NSE for currency pair USD/INR is strong comparing to other selected currency pairs. From the variance decomposition test, we found that there is almost no impact of variance in USD/INR spot rate on future rate variance forecast errors. It implies that the causal relationship between for USD/INR spot and future rates is strong and mature compared to the measured causal relationships for the remaining currency pairs. This study concludes that the price discovery process for currency pair USD/INR is better at NSE currency futures among the selected currency pairs.

\section{REFERENCES}

[1] Osler, C. L., Mende, A., \& Menkhoff, L. (2011). Price discovery in currency markets. Journal of International Money and Finance, 30(8), 1696-1718.

[2] Hasbrouck, J. (1995), "One security, many markets: determining the contributions to price discovery", Journal of Finance, 50(4), 1175-1199.

[3] Sehgal, S., Ahmad, W., \& Deisting, F. (2018), Business Cycle and Financial cycle Interdependence, Journal of Quantitative economics, 16(2), 337-362

[4] Srivastava, A. and Singh, M. (2015), "A study on pricing of currency futures in Indian currency market", International Journal of Research in Finance and Marketing, 5(6), 1-11.

[5] Sehgal, S., Ahmad, W., \& Deisting, F. (2018), Business Cycle and Financial cycle Interdependence, Journal of Quantitative economics, 16(2), 337-362

[6] Gonzalo, J. and Granger, C. (1995), "Estimation of common long-memory components in co integrated systems", Journal of Business and Economic Statistics, 13(1), 27-35.

[7] Hans R. Stoll and Robert E. Whaley (1990). The Dynamics of Stock Index and Stock Index Futures Returns. The Journal of Financial and Quantitative Analysis, 25(4), 441-468.

[8] Ira G. Kawaller, Paul D. Koch and Timothy W. Koch(1987).The Temporal Price Relationship Between S\&P 500 Futures and the S\&P 500 Index. The Journal of Finance, 42(5), 1309-1329.

[9] Lyons, Richard K. (2001). The Microstructure Approach to Exchange Rates. MIT Press, Cambridge, MA.

[10] Varuna Kharbanda and Archana Singh, (2017). Lead-lag relationship between futures and spot FX market in India. International Journal of Managerial Finance, 13(5), 560-577 